\title{
Growth and production of crisphead lettuce cultivars in protected cultivation and high temperatures
}

\author{
Eduardo Santana Aires ${ }^{1} \odot$, Carlos Alberto Aragão ${ }^{1} \oplus$, Itala Laiane Silva Gomes ${ }^{1} \odot$, Gilmário Noberto de Souza ${ }^{1} \oplus$, \\ Isa Gabriela Vieira de Andrade ${ }^{1} \odot$, Antônio Bruno Nunes de Oliveira ${ }^{1}{ }^{\circ}$, Willian Costa Bezerra ${ }^{1} \odot$, Jony Eishi Yuri²

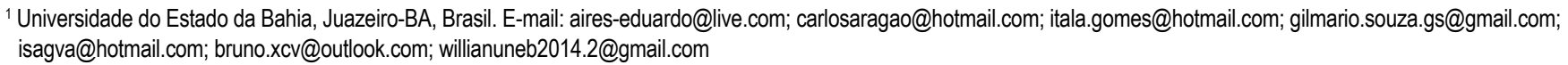

ABSTRACT: The objective of this study was to evaluate the effects of shading nets under lettuce in Juazeiro-BA from September to December 2017. To this end, a field experiment was set up with eight cultivars: Raider Plus, Balsamo, Irene, Rafaela, Iron Wood, Winslow, Great Lakes and Delícia in four production environments covered with red, chromatinet ${ }^{\circledR}$, black shading nets, and under full sun, with the a randomized blocks design in a $4 \times 8$ factorial scheme. The harvest was at 45 days after transplanting and the following was determined: head formation index, leaf length and width, plant height, stem length, head diameter, total and commercial fresh matter, total and commercial yield. Data were subjected to analysis of variance, and means were compared by the Scott-Knott test at 5\%. Significant effect was observed for the studied environments and cultivars, in addition to the interaction for all the studied variables. Shading altered the microclimatic conditions of the environments. The global solar radiation range from 17.6 to $19.5 \mathrm{MJ} \mathrm{m}^{-2}$ day $^{-1}$ was ideal for lettuce production. The cultivars that reached the highest commercial yields were Balsamo and Delícia, in an environment covered with the chromatinet ${ }^{\circledR}$ net.

\section{Desempenho de cultivares de alface americana em ambiente protegido em condições de temperaturas elevadas}

RESUMO: Objetivou-se avaliar os efeitos de telas de sombreamento sob a alface americana em Juazeiro-BA no período de setembro a dezembro, e para isso instalou-se em campo experimento com oito cultivares: Raider Plus, Balsamo, Irene, Rafaela, Iron Wood, Winslow, Great Lakes e Delícia em quatro ambientes de produção cobertos com tela vermelha, chromatinet ${ }^{\circledR}$ e preta, e em pleno sol, o delineamento foi de blocos ao caso em esquema fatorial $4 \times 8$. Colheu-se aos 45 dias após o transplantio e determinou-se: Índice de formação de cabeça, comprimento e largura da folha, altura da planta, comprimento do caule, diâmetro da cabeça, matéria fresca total e comercial, produção total e produtividade comercial. Os dados foram submetidos à análise de variância, e as médias foram comparadas pelo teste de Scott-Knott, a 5\%. Observou-se efeito significativo para os ambientes e cultivares estudados, além da interação para todas as variáveis estudadas. As condições microclimáticas dos ambientes foram alteradas pela cobertura com telas. A faixa de 17,6 a $19,5 \mathrm{MJ} \mathrm{m}^{-2} \mathrm{dia}^{-1}$ de radiação solar global foi a ideal para produção de alface americana. As cultivares que alcançaram maiores produtividades comercial foram: Balsamo e Delícia em ambiente coberto com tela chromatinet ${ }^{\circledR}$.

Palavras-chave: Lactuca sativa var. capitata; semiárido; telas de sombreamento 


\section{Introduction}

The increase in demand for quality vegetables linked to a regular supply offer makes the producer seek technologies that aim at a better periodicity in their production. For the conditions of the Lower-middle São Francisco Valley, one of the alternatives is using shading nets that can generate a microclimate favorable to the development of vegetables. In this region, the average temperature varies from $24.4^{\circ} \mathrm{C}$ to $28.5^{\circ} \mathrm{C}$, reaching up to a maximum of $34{ }^{\circ} \mathrm{C}$, and it also has a very high radiation supply, reaching to $21.3 \mathrm{MJ} \mathrm{m}^{-2}$ day $^{-1}$ (Teixeira, 2010), with such conditions being limiting for some vegetables.

Among the vegetables, lettuce is among the most present on the Brazilian diet, considered as the most popular leaf vegetables. It is estimated that around 35 thousand hectares of this vegetable are annually cultivated in Brazil, both in intensive production and by family producers, creating around five jobs per hectare (Sousa et al., 2014). Its cultivation is most often found in small rural properties where family farming predominates, thus revealing its social and economic importance (Santi et al., 2013). Among the types of lettuce grown, currently, the crisphead lettuce has been standing out. This is mainly because this type has crunchy, dark green external leaves and yellow or white internal leaves, overlapping similarly to cabbage (Yuri et al., 2004). As such, this group already occupies the second position among the most commercialized varieties in CEAGESP in 2017, with about $42 \%$ of the total volume (CEAGESP, 2018).

The Brazilian states that produce the most lettuce in country are São Paulo, Rio de Janeiro and Minas Gerais, with areas of $21,000 \mathrm{ha}, 1,900 \mathrm{ha}$ and $625 \mathrm{ha}$, respectively, in the 2015/2016 summer crop (Hortifruit. Cepea, 2016). Regarding the Northeastern Brazil, the production difficulty is due to the high temperatures in this region, reason for why consistent production data that can be compared with other regions of the country are not observed.

Production of these cultivars can be impaired in some regions, especially during the summer months, as unfavorable temperatures (over $30{ }^{\circ} \mathrm{C}$ during the day and $16{ }^{\circ} \mathrm{C}$ at night) increase the risk of early bolting, tip burn, and latex formation (Blind et al., 2018).

By means of genetic improvement, cultivars that are more tolerant to high temperatures and long photoperiod have been developed, that is, adapted to tropical conditions, without stimulating bolting and latex production. Coupled to this, the technique of using shading nets to protect the crops can increase the production of crisphead lettuce, enabling the production all along the year, even during periods of high temperatures, or between crop seasons.

Using a protected environment for lettuce production allows its cultivation in unfavorable conditions, when compared to conventional cultivation in open field. Neves et al. (2016), observed that for the conditions of high temperatures in the municipality of Cárceres-MT, using thermoreflective-shading nets reached a crisphead lettuce yield of $27 \mathrm{t} \mathrm{ha}^{-1}$, while plants conducted under full sun reached $15 \mathrm{t} \mathrm{ha}^{-1}$. Shading nets can also influence plant physiological processes as well as production and quality. Crisphead lettuce grown in South Africa under net with $40 \%$ shading increased the dry mass of the leaves and the percentage of commercial production (Ntsoane et al., 2016).

In view of this, the objective of this study was to evaluate the performance of crisphead lettuce (Lactuca sativa var. Capitata) cultivars in different shaded environments with black, chromatinet ${ }^{\circ}$ and red nets and under full sun, under conditions of high temperatures.

\section{Materials and Methods}

The experiment was conducted in the period from September to December 2017, in the vegetables experimental field from the Department of Technology and Social Sciences - DTCS, part of State University of Bahia - UNEB, in the municipality of Juizaeiro-BA. According to Köppen, the region possesses BSwh climate type, and it is located at the coordinates $9^{\circ} 24$ of latitude , $40^{\circ} 26$ of longitude and $375 \mathrm{~m}$ of altitude. The average annual temperature is $23.6{ }^{\circ} \mathrm{C}$, relative humidity of the air is $61.7 \%$, annual precipitation is $455 \mathrm{~mm}$, and A-Class tank evaporation is of $1800 \mathrm{~mm}$, with annual insolation of 11 hours day ${ }^{-1}$.

The soil of the area was classified as a Fluvent Entisol (Fluvic Neossol, by Embrapa, 2013) and its 0-20 layer displayed the following chemical characteristics: $\mathrm{pH}\left(\mathrm{H}_{2} \mathrm{O}\right)=6.42 ; \mathrm{P}=56$ $\mathrm{mg} \mathrm{dm}{ }^{-3} ; \mathrm{K}=0.22 \mathrm{cmolc} \mathrm{dm}^{-3} ; \mathrm{Ca}=5.0 \mathrm{cmolc} \mathrm{dm}^{-3} ; \mathrm{Mg}=1.70$ cmolc dm ${ }^{-3} ; \mathrm{Al}=0.0 \mathrm{cmolc} \mathrm{dm}^{-3} ; \mathrm{CEC}=7.01 \mathrm{cmolc} \mathrm{dm}^{-3} ; \mathrm{CE}=$ $0.77 \mathrm{dS} \mathrm{m}^{-1}$.

Evaluated factors were cultivars and shading nets, with thirty-two treatments arranged in a randomized block design and in an $8 \times 4$ factorial scheme, with three replicates. Eight cultivars of crisphead lettuce were used: Raider Plus, Balsamo, Irene, Iron Wood, Winslow, Rafaela, Delícia and Great Lakes, and four environments, composed by black (BN), red (RN) and chromatinet ${ }^{\circ}(\mathrm{CN})$ shading nets and a control under full sun (PS). The structures of the shaded environments had a ceiling height of $2.00 \mathrm{~m}, 18$ meters in length and lateral opening; the nets were fixed on eucalyptus stakes with wire. Sowing was performed on 10/10/2017 in expanded polystyrene trays, filled up with the Plantmax ${ }^{\circ}$ commercial substrate. The trays were placed on $0.5 \mathrm{~m}$ high benches, under a protected environment shaded by a $50 \%$ black shading net. The seedlings were transplanted twenty days after sowing, in four rows with spacing of $0.25 \times 0.25 \mathrm{~m}$.

The soil was prepared with plowing, harrowing and the raising of beds to $0.3 \mathrm{~m}$ high, with each bed being $18.0 \mathrm{~m}$ long by $1.5 \mathrm{~m}$ wide, and each experimental plot was $0.75 \mathrm{x}$ $1.50 \mathrm{~m}$, with twelve plants. Planting fertilization was based on the recommendation for lettuce in the fertilization manual from the Bahia state (CEFSBA, 1989), and according to the soil analysis, $6.3 \mathrm{~kg} \mathrm{ha}^{-1}$ of $\mathrm{N}$ and $21.3 \mathrm{~kg} \mathrm{ha}^{-1}$ of $\mathrm{P}_{2} \mathrm{O}_{5}$ were applied, by using urea $(44 \% \mathrm{~N})$ and simple superphosphate $\left(18 \% \mathrm{P}_{2} \mathrm{O}_{5}\right)$ as sources. Topdressing fertilization was performed at 18 days 
after transplanting, by adding $38 \mathrm{~kg} \mathrm{ha}^{-1}$ of $\mathrm{N}$ and $26.0 \mathrm{~kg} \mathrm{ha}^{-1}$ of $\mathrm{Ca}$, and calcium nitrate ( $15 \% \mathrm{~N}$ and $19 \% \mathrm{Ca}$ ) as the source.

For the purpose of irrigation management, samples were collected from the 0 -20 layer of the soil with the beds ready for the physical-hydric characterization, and when possessing this result, the water retention curve was made. From this curve, the values of the matric potential were converted into gravimetric humidity. The applied depth in each irrigation was determined based on the matric potentials, by using the readings from the means of three tensiometers per environment, installed at 10 $\mathrm{cm}$ depth, representing the $0-20 \mathrm{~cm}$ layer.

After estimating the irrigation depth based on the tensiometers readings, it was applied via a micro-sprinkling system, with 13 emitters per bed and a flow rate of 10 L.h $^{-1}$ per emitter. For phytosanitary and weed control, the treatments used were the ones that are commonly employed in the crop, according to Yuri et al. (2017).

In cultivation environments with black, red and chromatinet ${ }^{\circledR}$ shading nets, the microclimates were monitored by meteorological sensors installed at a $50 \mathrm{~cm}$ height and interconnected to an automatic data system (Datalogger), programmed to perform readings every five seconds and hourly means. The following meteorological elements were monitored in each environment: air temperature (mean, maximum and minimum), relative air humidity (mean, maximum and minimum) and global radiation. Sensors remained installed in each environment for 5 days, so it was possible to correlate the data between the shaded environments and the full sun based on the weather station located $300 \mathrm{~m}$ from the experimental area.

Harvesting took place at 45 days after transplanting. Just before this operation, the cultivars head formation was evaluated on a visual scale ranging from 1 to 3 (1 - No head formation; 2 - Malformed head; 3 - Formed head). Subsequently, with the plants harvested, the head circumference $(\mathrm{cm})$ and the plant height $(\mathrm{cm})$ were measured. Moreover, the lettuce head was cut in half, making it possible measuring the length of the stem with a graduated ruler $(\mathrm{cm})$. After the cutting, the largest leaf from each cultivar was selected and its length $(\mathrm{cm})$ and width $(\mathrm{cm})$ were measured. Total fresh mass $\left(\mathrm{g} \mathrm{plant}^{-1}\right.$ ) was obtained by cutting the plants very close to the soil and weighing them on a digital scale, while the commercial fresh mass (g plant ${ }^{-1}$ ) was obtained by weighing only the head, removing the outer leaves. With the results of total and commercial fresh mass, extrapolation was performed in order to calculate total and commercial yield $\left(\mathrm{t} \mathrm{ha}^{-1}\right)$.

Collected data were subjected to analysis of variance, by using the $\mathrm{F}$ test to compare the mean squares at $5 \%$ probability and the means were compared by the Scott-Knott test, at $5 \%$ probability, employing the SISVAR 5.0 program (Ferreira, 2010).

\section{Results and Discussion}

Values of the mean temperature during the period were $28.1^{\circ} \mathrm{C} ; 28.0^{\circ} \mathrm{C} ; 27.6^{\circ} \mathrm{C}$ and $27.6^{\circ} \mathrm{C}$ for the FS, CN, RN and BN environments, respectively. This microclimate characteristic was not significantly altered by the nets shading, and in general, the full sun was about $0.5^{\circ} \mathrm{C}$ higher than the shaded environments with black and chromatinet ${ }^{\circ}$ nets, with a similar value for the red net. All studied environments exceeded the ideal average temperature for growing lettuce, $22{ }^{\circ} \mathrm{C}$ (Lemos Neto et al., 2017). Santiago et al. (2018) observed an increase in the average temperature in shaded environments when compared to open sky cultivation, a fact which was not observed in the present research. This can be explained by the smaller area of the protected beds and their rectangular shape, with narrow width and great length, thus promoting better exchanges gases due to the wind and natural convection. In other words, the air circulation favored by the side vents did not allow the temperature to increase in the beds shaded with black and chromatinet ${ }^{\oplus}$ nets.

Regarding total radiation (Figure 1), lower values were verified for black and chromatinet ${ }^{\circ}$ nets, with a reduction of 40 and $45 \%$, respectively, with the red net having promoted an $18 \%$ reduction. Absorption and reflection promoted by the shadings reduce the incidence of solar radiation inside the protected environment (Rebouças et al., 2015). The average radiation observed in the period was about $30 \mathrm{MJ} \mathrm{m}^{-2}$ day $^{-1}$, $25 \mathrm{MJ} \mathrm{m}^{-2}$ day $^{-1}, 18 \mathrm{MJ} \mathrm{m}^{-2}$ day $^{-1}$ and $16 \mathrm{MJ} \mathrm{m}^{-2}$ day $^{-1}$ under full sun, $\mathrm{RN}, \mathrm{CN}$ and $\mathrm{BN}$, respectively. The relative humidity ( $\mathrm{RU}$ ) data accompanies the mean temperature, and were higher in the black and chromatinet ${ }^{\circ}$ nets in the order of approximately $5 \%$, that is, the environments with these nets showed higher relative humidity than the environment under full sun and the red net. Microclimate conditions generated by crop protection can directly affect their growth and development, specially the air temperature and relative humidity (Hassanien \& Ming, 2017). Solar radiation is the main energy source for the environment-soil-plant system, and it mainly regulates evaporation, hence, in shaded environments that had lower values of total solar radiation, the evaporation was lower, ensuring higher water levels in the system and consequently, making the environment more humid.

Table 1displays the mean values of leaf length and width of lettuce plants from the different cultivars tested. The results were similar among the studied cultivars in environments protected with the shading nets; however, a decrease was observed in these values for the environment under full sun. For leaf width, the cultivars Rafaela and Delícia had lower values under the influence of the red net when compared to the black and chromatinet ${ }^{\circ}$ nets, which can be explained by the higher solar radiation transmittance of this net, reason why this variable decreased and had values similar to those of the full sun.

These variables are correlated with the leaf area index (LAI). The greater the length and width of the leaf, the greater the LAI will also be. Therefore, cultivars under the effect of shading nets have higher LAl when compared to those produced under full sun, and this is due to the leaf area increase for light interception. Sales et al. (2014), observed higher LAI values of leaf lettuce gronw under with thermoreflective and 


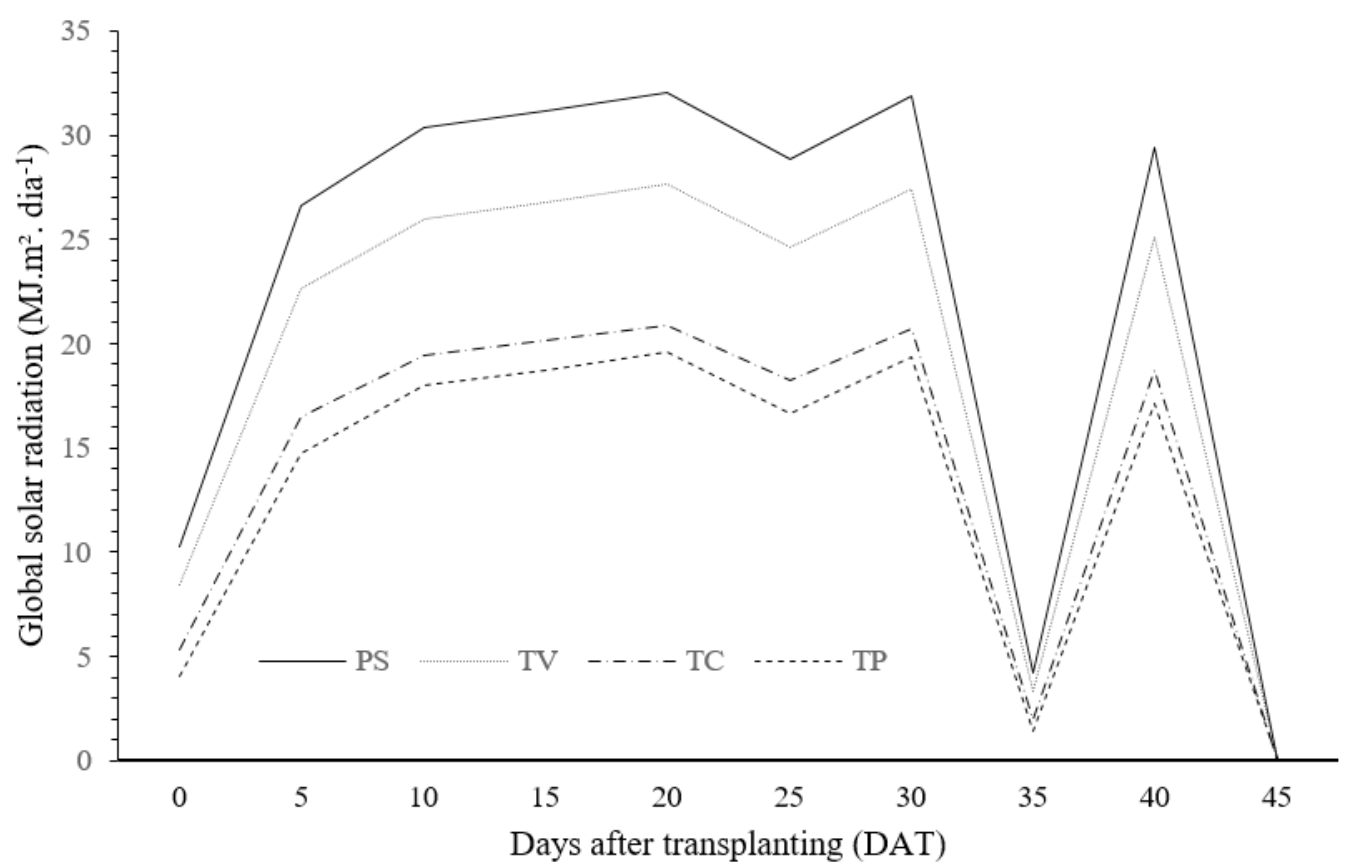

Figure 1. Mean values of total radiation (TR) in $\mathrm{MJ} \mathrm{m}^{-2}$ from the shaded and full sun environments.

Table 1. Mean values of leaf length and width of lettuce cultivars in a semi-protected environment in the Lower-middle São Francisco Valley, Juazeiro-BA (2017).

\begin{tabular}{|c|c|c|c|c|c|c|c|c|}
\hline \multirow{3}{*}{ Cultivars } & \multicolumn{4}{|c|}{ Leaf length $(\mathrm{cm})$} & \multicolumn{4}{|c|}{ Leaf width $(\mathrm{cm})$} \\
\hline & \multicolumn{4}{|c|}{ Environments } & \multicolumn{4}{|c|}{ Environments } \\
\hline & RN & $\mathrm{CN}$ & $\mathrm{BN}$ & FS & RN & $\mathrm{CN}$ & $\mathrm{BN}$ & FS \\
\hline Raider Plus & $20.10 \mathrm{Aa}$ & $18.26 \mathrm{Aa}$ & $18.70 \mathrm{Aa}$ & $17.55 \mathrm{Aa}$ & $20.73 \mathrm{Aa}$ & $18.58 \mathrm{Aa}$ & $19.66 \mathrm{Aa}$ & $16.15 \mathrm{Ab}$ \\
\hline Balsamo & $19.51 \mathrm{Aa}$ & $20.41 \mathrm{Aa}$ & $19.95 \mathrm{Aa}$ & $17.45 \mathrm{Aa}$ & $20.78 \mathrm{Aa}$ & $21.35 \mathrm{Aa}$ & $21.70 \mathrm{Aa}$ & $16.27 \mathrm{Ab}$ \\
\hline Irene & $20.35 \mathrm{Aa}$ & $18.91 \mathrm{Aa}$ & $20.26 \mathrm{Aa}$ & $15.08 \mathrm{Ab}$ & 18.78 Aa & $20.48 \mathrm{Aa}$ & $20.63 \mathrm{Aa}$ & $14.13 \mathrm{Bb}$ \\
\hline Rafaela & $19.41 \mathrm{Aa}$ & $20.05 \mathrm{Aa}$ & $19.53 \mathrm{Aa}$ & $16.33 \mathrm{Ab}$ & $18.50 \mathrm{Ab}$ & $21.49 \mathrm{Aa}$ & $20.33 \mathrm{Aa}$ & $16.85 \mathrm{Ab}$ \\
\hline Great Lakes & $21.36 \mathrm{Aa}$ & $20.65 \mathrm{Aa}$ & $20.55 \mathrm{Aa}$ & $16.11 \mathrm{Ab}$ & $19.18 \mathrm{Aa}$ & $17.88 \mathrm{Aa}$ & $19.78 \mathrm{Aa}$ & $12.36 \mathrm{Bb}$ \\
\hline Delícia & $18.90 \mathrm{Aa}$ & $19.78 \mathrm{Aa}$ & $20.80 \mathrm{Aa}$ & $16.72 \mathrm{Aa}$ & $18.50 \mathrm{Ab}$ & $20.78 \mathrm{Aa}$ & $20.73 \mathrm{Aa}$ & $16.90 \mathrm{Ab}$ \\
\hline CV (\%) & \multicolumn{4}{|c|}{10.27} & \multicolumn{4}{|c|}{10.09} \\
\hline
\end{tabular}

RN - Red Net; CN - Chromatinet ${ }^{\circ}$ Net; BN - Black Net e FS - Full Sun. Different lowercase letters in the row and capitals letters in the column differ statistically ( $<$ < 0.05) by the Scott Knott test.

black nets. This research corroborates with this author, where the crisphead lettuce grown under shade has a greater leaf expansion.

The head circumference of crisphead lettuce is very important for the producer, since the remuneration is paid according to the size of the head, it is also important as well for the industry because it affects the processing income (Gonçalves et al., 2014). Analyzing this variable (Table 2), there is a decrease in cultivars under full sun, except for the Rafaela cultivar, which showed no significant difference $(p \geq$ $0.05)$ regardless of the studied environment. Although this cultivar did not reach high levels of this variable, it was able to form the commercial lettuce product and to emerge from the other cultivars in the environment under full sun, with no shading.

Still regarding cultivation under full sun, the cultivars Irene and Great Lakes were not able to form heads, with the latter not forming in any of the studied environments, demonstrating its low adaptation for cultivation in periods of high temperature and solar radiation.

Among the seven cultivars that formed head, three showed greater circumferences when cultivated shaded with red net: Raider Plus, Irene and Winslow. Neves et al. (2016) observed that the environment factor enabled plants with significant differences in the head diameter, with environments with $30 \%$ and $50 \%$ similar to each other and higher than the full sun. A different fact from that observed in the present study, where the majority of cultivars under the red net influence with about $30 \%$ of shading had a circumference superior to those cultivated under black net with $45 \%$ of shading.

The stem length variable (Table 2 ) is discussed according to the final destination of crisphead lettuce; if it is for industrial processing, the stem must be reduced enough to minimize losses during the processing; while for the fresh consumption, a length of up to $9.0 \mathrm{~cm}$ is acceptable (Yuri et al., 2004). According to this classification, only the Rafaela cultivar had 
Table 2. Mean values of head circumference and stem length from lettuce cultivars in a semi-protected environment in the São Francisco Valley. Juazeiro-BA (2017).

\begin{tabular}{|c|c|c|c|c|c|c|c|c|}
\hline \multirow{3}{*}{ Cultivars } & \multicolumn{4}{|c|}{ Head circumference $(\mathrm{cm})$} & \multicolumn{4}{|c|}{ Stem length $(\mathrm{cm})$} \\
\hline & \multicolumn{4}{|c|}{ Environments } & \multicolumn{4}{|c|}{ Environments } \\
\hline & RN & $\mathrm{CN}$ & BN & FS & RN & $\mathrm{CN}$ & BN & FS \\
\hline Raider Plus & $36.81 \mathrm{Aa}$ & $29.72 \mathrm{Bc}$ & $32.75 \mathrm{Ab}$ & $25.30 \mathrm{Ad}$ & $8.01 \mathrm{Ba}$ & $7.15 \mathrm{Ba}$ & $6.55 \mathrm{Aa}$ & $6.35 \mathrm{Aa}$ \\
\hline Balsamo & $29.29 \mathrm{Bb}$ & $37.64 \mathrm{Aa}$ & $28.65 \mathrm{Bb}$ & $20.45 \mathrm{Bc}$ & $8.71 \mathrm{Ba}$ & $6.86 \mathrm{Bb}$ & $5.65 \mathrm{Ab}$ & $5.42 \mathrm{Ab}$ \\
\hline Irene & $37.29 \mathrm{Aa}$ & $32.05 \mathrm{Bb}$ & $32.78 \mathrm{Ab}$ & $0.0 \mathrm{Cc}$ & $7.28 \mathrm{Ba}$ & 7.35 Ba & $6.90 \mathrm{Aa}$ & $5.70 \mathrm{Aa}$ \\
\hline Rafaela & $29.11 \mathrm{Ba}$ & $29.43 \mathrm{Ba}$ & $30.33 \mathrm{Ba}$ & $26.81 \mathrm{Aa}$ & $11.7 \mathrm{Aa}$ & 10.3 Aa & $9.23 \mathrm{Aa}$ & $6.31 \mathrm{Ab}$ \\
\hline Iron Wood & $31.19 \mathrm{Bb}$ & $36.04 \mathrm{Aa}$ & $28.85 \mathrm{Bb}$ & $22.51 \mathrm{Bc}$ & $8.35 \mathrm{Ba}$ & $5.98 \mathrm{Ba}$ & $6.41 \mathrm{Aa}$ & $3.10 \mathrm{Ab}$ \\
\hline Winslow & $36.66 \mathrm{Aa}$ & $30.72 \mathrm{Bb}$ & $30.84 \mathrm{Bb}$ & $22.75 \mathrm{AC}$ & $8.31 \mathrm{Ba}$ & $6.20 \mathrm{Ba}$ & $6.86 \mathrm{Aa}$ & $5.45 \mathrm{Aa}$ \\
\hline Great Lakes & $0.0 \mathrm{Ca}$ & $0.0 \mathrm{Ca}$ & $0.0 \mathrm{Ca}$ & $0.0 \mathrm{Ca}$ & $7.66 \mathrm{Ba}$ & $7.06 \mathrm{Ba}$ & $7.60 \mathrm{Aa}$ & $4.71 \mathrm{Ab}$ \\
\hline Delícia & $31.76 \mathrm{Ba}$ & $35.19 \mathrm{Aa}$ & $35.92 \mathrm{Aa}$ & $23.90 \mathrm{Bb}$ & $10.6 \mathrm{Aa}$ & $6.45 \mathrm{Bb}$ & $6.06 \mathrm{Ab}$ & $4.72 \mathrm{Ab}$ \\
\hline CV (\%) & \multicolumn{4}{|c|}{9.23} & \multicolumn{4}{|c|}{22.50} \\
\hline
\end{tabular}

RN - Red Net; CN - Chromatinet ${ }^{\circ}$ Net; BN - Black Net e FS - Full Sun. Different lowercase letters in the row and capitals letters in the column differ statistically ( $p<0.05$ ) by the Scott Knott test.

excessive stem elongation in protected environments, while the cultivars Irene, Winslow, Iron Wood, Delícia, Balsamo and Raider Plus all presented diminished stems in all environments, demonstrating capacity for both consumption in natura and for processing.

Plants exposed to full sun did not show stem elongation, which would be an indication of early weighing caused by high temperatures. As stated by Aquino et al. (2017), what evinces the bolting is the stem elongation characterized by the passage from the vegetative to the reproductive cycle. Most cultivars in this environment had poor formation or did not form the commercial head at all, as well as no biomass accumulation that reflected in the total production, which can be attributed to the high temperature and solar radiation, especially the latter, reaching values of $30 \mathrm{MJ} \mathrm{m}^{-2} \mathrm{day}^{-1}$.

Variations in the environment not considered as favorable can lead to changes in individuals regarding morphological profiles and yield components in a very dynamic way (Blind et al., 2015). Environments under the shading nets effect had average temperatures higher than the optimal for growing lettuce; however, the studied cultivars obtained higher rates of head formation (Table 3 ) in these environments when compared to cultivation under full sun. The cultivars Raider Plus, Balsamo, Irene, Rafaela, Iron Wood, Winslow and Delícia all formed commercial heads when grown in environments with chromatinet ${ }^{\circ}$ and black nets, demonstrating their efficiency in growing crisphead lettuce under high temperature conditions.

Malformation of the head, identified when the arrangement of the interlaced leaves is irregular, was more frequent in the environment covered with red net for the Irene and Rafaela cultivars. The fact that the environments protected with black and chromatinet ${ }^{\circ}$ nets were superior in the head formation of crisphead lettuce cultivars may be due to less radiation and temperature when compared to full sun and red net environments, which may have influenced the arrangement of interlaced leaves.

Raider Plus cultivar was the only one among the evaluated in this study that did not differ between environments regarding plant height (Table 3), it also formed a head in both shaded environments and under full sun. The other cultivars reduced their height under full sun when compared to a protected environment, since plants subjected to shading may have higher heights than those grown under full light. This behavior can be explained by the reduction in direct solar radiation caused by the use of shading nets; in this way, plants subjected to these conditions tend to increase their height in order to improve their capture of sunlight.

Shaded environments can promote a higher relative humidity of the air when compared to full sun, a fact observed in the present research. The humidity increase consequently

Table 3. Mean values for plant height and head formation index of crisphead lettuce cultivars in a semi-protected environment in the Lower-middle São Francisco Valley, Juazeiro-BA (2017).

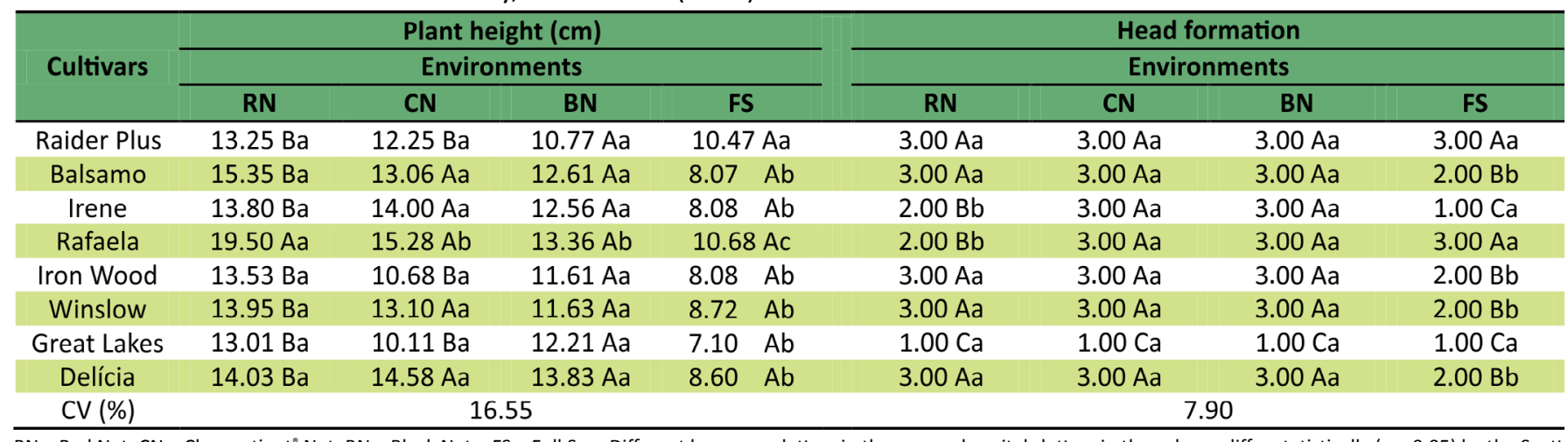

RN - Red Net; CN - Chromatinet ${ }^{g}$ Net; BN - Black Net e FS - Full Sun. Different lowercase letters in the row and capitals letters in the column differ statistically ( $p<0.05$ ) by the Scott Knott test. 
enables a greater water potential in the leaf, so the plant tends to accumulate dry matter due to less stress and better absorption of water and nutrients. This could be observed in the present research, where the crisphead lettuce cultivars accumulated more fresh matter in shaded environments.

In a study on butterhead lettuce production under shading nets in the region of Cáceres-MT, Diamante et al. (2013) observed a significant interaction between environment and cultivars only for the commercial dry matter variable, differing from the present study, where all variables showed significant interaction between studied environments and cultivars. This difference may be related to the study conduction period and the lettuce variety used in the study, where the butterhead type may have a higher tolerance to high temperatures when compared to crisphead lettuce.

Accumulation of fresh matter and, consequently, total production, is directly linked to the each cultivar capacity to efficiently use the conditions of climate, soil and water. Hence, the cultivars responded differently to the studied protected environments concerning the production of fresh matter, as displayed in tables 4 and 5 .

On total fresh matter and total production, significant differences were found between cultivars, nets and the interaction between them. The lowest CFM values were found in cultivation under full sun, while the highest were under chromatinet ${ }^{\circ}$ nets. All studied cultivars underperformed when grown under full sun, and this can be explained by the study conduction period, from October to November, when the highest temperatures and solar radiation are present in the Lower-middle São Francisco Valley region.

Higher values of fresh matter may be a consequence of the greater length and width of the leaves of the lettuce plants grown under black and chromatinet ${ }^{\circ}$ shading nets, a fact also noted by Kosma et al. (2013), who also stated that greater fresh weight is associated with greater leaf length and width.

The cultivar with the highest total fresh matter accumulation was Balsamo under chromatinet ${ }^{\circ}$ net with a mean value of $409.50 \mathrm{~g} \mathrm{plant}^{-1}$, and this same genotype had a $48 \%$ reduction in this variable when grown under full sun. Yuri et al. (2017), for this same variety, observed values of 875 g plant ${ }^{-1}$ in the same region of the present research; probably the difference is due to the production periods of that study, which had mild temperatures, while this present research was conducted in high temperatures.

Demand in the Brazilian market is for two types of crisphead lettuces: one type with a compact "head" for minimal processing, in which the lettuce is washed, chopped, sanitized and packaged (industry), directed mainly to large supermarket chains or snack bars; and the other one with a less compact "head" formation, for sale in markets and fairs (Yuri et al., 2017).

In this context, when evaluating commercial yield $\left(\mathrm{t} \mathrm{ha}^{-1}\right)$, where only the weight of the "head" was counted (Table 5), there are increments of up to $100 \%$ in environments shaded with chromatinet ${ }^{\circ}$ and black nets. Also under conditions of high temperatures, in a study analyzing the effect of shading nets and open fields on lettuce in the summer, llic et al. (2017) observed an increase in head weight and, consequently, in commercial yield by using black, and red shading nets with $50 \%$ solar radiation block.

Observing the shading nets factor in terms of commercial yield ( $\left.t \mathrm{ha}^{-1}\right)$, using red nets promoted higher values for the cultivars Raider Plus, Balsamo, Iron Wood, Winslow and Delícia, of $21.4 ; 26.8 ; 21.2 ; 23.78$ and $19.4 \mathrm{t} \mathrm{ha}^{-1}$, respectively. While on the chromatinet ${ }^{\circ}$ type net, the cultivars with higher values were Balsamo, Irene, Rafaela and Delícia, with yield of 33.6; $27.8 ; 27.6$ and $31.2 \mathrm{t} \mathrm{ha}^{-1}$ without, however, differing from each other.

When using black net as shading, all cultivars had similar behavior in terms of commercial yield, except for the Great Lakes cultivar, which did not form heads in any studied environment, and its values ranged from 22.0 to $28.0 \mathrm{t} \mathrm{ha}^{-1}$. Even without attaining maximum yield as it was with the chromatinet ${ }^{\circ}$ type, the black net proved to be efficient for producing lettuce by reducing the temperature, increasing the relative humidity of the air and with increments response of more than $100 \%$ when compared to full sun. Shading nets are cheaper than diffuser-types nets such as chromatinet ${ }^{\circ}$ and depending on the technological level adopted by the producer, diffuser nets are not economically viable. As noted by Rampazzo et al.

Table 4. Mean values of total and commercial fresh matter production from lettuce cultivars in a semi-protected environment in the Lower-middle São Francisco Valley, Juazeiro-BA (2017).

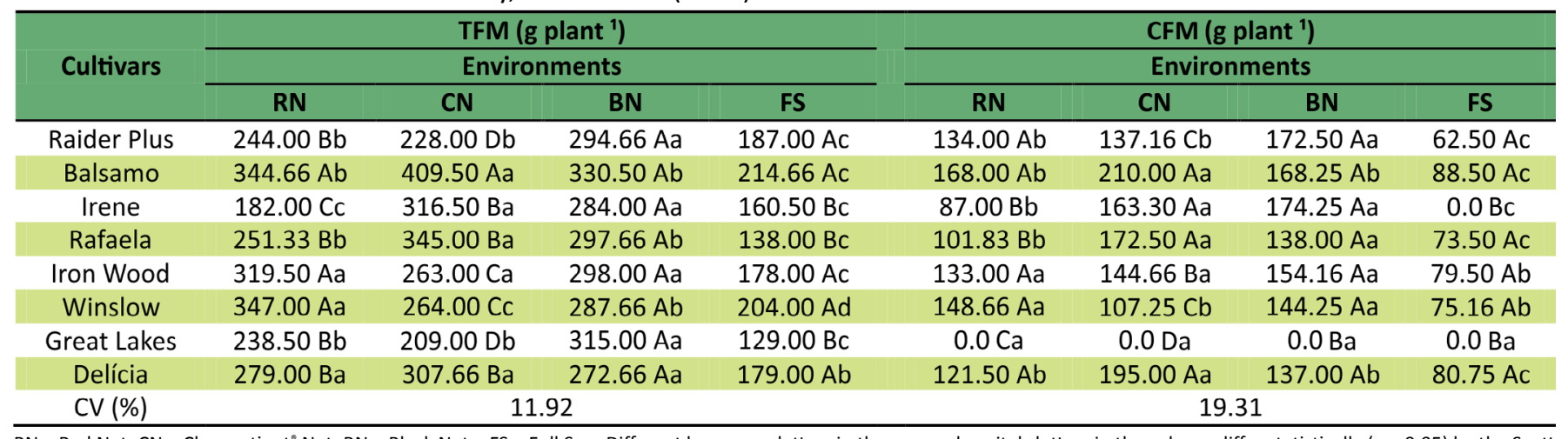

RN - Red Net; CN - Chromatinet ${ }^{\circ}$ Net; BN - Black Net e FS - Full Sun. Different lowercase letters in the row and capitals letters in the column differ statistically ( $\mathrm{p}<0.05$ ) by the Scott Knott test. 
Table 5. Mean values of total production and commercial yield from lettuce cultivars in a semi-protected environment in the Lower-middle São Francisco Valley, Juazeiro-BA (2017).

\begin{tabular}{|c|c|c|c|c|c|c|c|c|}
\hline \multirow{3}{*}{ Cultivars } & \multicolumn{4}{|c|}{ Total yield (t ha') } & \multicolumn{4}{|c|}{ Commercial yield ( $t$ ha') } \\
\hline & \multicolumn{4}{|c|}{ Environments } & \multicolumn{4}{|c|}{ Environments } \\
\hline & RN & $\mathrm{CN}$ & BN & FS & RN & $\mathrm{CN}$ & BN & FS \\
\hline Raider Plus & $39.04 \mathrm{Bb}$ & $36.48 \mathrm{Db}$ & $47.14 \mathrm{Aa}$ & $29.92 \mathrm{Ac}$ & $21.44 \mathrm{Ab}$ & $21.94 \mathrm{Bb}$ & $27.60 \mathrm{Aa}$ & $10.00 \mathrm{Ac}$ \\
\hline Balsamo & $55.14 \mathrm{Ab}$ & $65.52 \mathrm{Aa}$ & $52.80 \mathrm{Ab}$ & $34.34 \mathrm{Ac}$ & $26.88 \mathrm{Ab}$ & $33.60 \mathrm{Aa}$ & $26.92 \mathrm{Ab}$ & $13.20 \mathrm{Ac}$ \\
\hline Irene & $29.12 \mathrm{Cb}$ & $50.64 \mathrm{Ba}$ & $45.44 \mathrm{Aa}$ & $25.68 \mathrm{Bb}$ & $13.92 \mathrm{Bb}$ & $27.88 \mathrm{Aa}$ & $26.13 \mathrm{Aa}$ & $0.0 \mathrm{Bc}$ \\
\hline Rafaela & $40.21 \mathrm{Bb}$ & $55.20 \mathrm{Ba}$ & $47.62 \mathrm{Aa}$ & $22.08 \mathrm{BC}$ & $16.29 \mathrm{Bb}$ & $27.60 \mathrm{Aa}$ & $22.08 \mathrm{Aa}$ & $11.76 \mathrm{Ab}$ \\
\hline Iron Wood & $51.12 \mathrm{Aa}$ & $42.08 \mathrm{Ca}$ & $47.68 \mathrm{Aa}$ & $28.48 \mathrm{Ac}$ & $21.28 \mathrm{Aa}$ & $24.66 \mathrm{Ba}$ & $23.14 \mathrm{Aa}$ & $12.72 \mathrm{Ab}$ \\
\hline Winslow & $55.52 \mathrm{Aa}$ & $42.24 \mathrm{Cc}$ & $46.02 \mathrm{Ab}$ & $32.64 \mathrm{Ad}$ & $23.78 \mathrm{Aa}$ & $17.16 \mathrm{Cb}$ & $23.08 \mathrm{Aa}$ & $12.02 \mathrm{Ab}$ \\
\hline Great Lakes & $38.16 \mathrm{Bb}$ & $33.44 \mathrm{Db}$ & $50.40 \mathrm{Aa}$ & $20.64 \mathrm{Bc}$ & $0.0 \mathrm{Ca}$ & $0.0 \mathrm{Da}$ & $0.0 \mathrm{Ba}$ & $0.0 \mathrm{Ba}$ \\
\hline Delícia & $44.64 \mathrm{Ba}$ & $49.22 \mathrm{Ba}$ & $43.62 \mathrm{Aa}$ & $28.64 \mathrm{Ab}$ & $19.4 \mathrm{Ab}$ & $31.20 \mathrm{Aa}$ & $21.92 \mathrm{Ab}$ & $12.92 \mathrm{Ac}$ \\
\hline CV (\%) & \multicolumn{4}{|c|}{11.92} & \multicolumn{4}{|c|}{19.31} \\
\hline
\end{tabular}

RN - Red Net; CN - Chromatinet ${ }^{\circ}$ Net; BN - Black Net e FS - Full Sun. Different lowercase letters in the row and capitals letters in the column differ statistically ( $\mathrm{p}<0.05$ ) by the Scott Knott test.

(2014), which indicates the use of 40 and $50 \%$ shading nets for the municipality of Cárceres-MT, as these showed greater efficiency in reducing environmental parameters and lower cost (30\%) in relation to the thermal reflector.

Yields greater than $30 \mathrm{t} \mathrm{ha}^{-1}$ were obtained by the cultivars Balsamo and Delícia, both under chromatinet ${ }^{\circ}$, with the latter reaching a total production of less than $50 \mathrm{t} \mathrm{ha}^{-1}$, but also forming a heavier commercial head and reaching high yield. This demonstrates the processing capacity of the Delícia cultivar in industry, as it has higher head yield when produced in a semi-protected environment under a chromatinet ${ }^{\circ}$ net.

The highest means of yield and total production found were 33.6 and $65.5 \mathrm{t} \mathrm{ha}^{-1}$, respectively. These values are higher than what was observed for crisphead lettuce cultivars in Carcéres-MT, where yield indexes ranged from 15 to $27 \mathrm{t}$ ha $^{-1}$ with an average temperature of $29^{\circ} \mathrm{C}$ (Neves et al., 2016) were verified. Meanwhile, Yuri et al. (2017) found values above $40 \mathrm{tha}-{ }^{1}$ in the region of Petrolina-PE, with an average temperature of $22^{\circ} \mathrm{C}$, with these results being higher than the ones from this research.

Although climatic conditions for growing crisphead lettuce have not been met as proposed by Santi et al. (2010), the environments shaded with nets, mainly the black and chromatinet $^{\circ}$ ones, were not limiting to this vegetable cultivation, which is confirmed by the satisfactory yields attained. The created microclimate from using shading favored the performance of some cultivars that were able to use the environments conditions more efficiently.

In view of this, using shade nets over the beds enabled lower average temperatures and higher relative humidity values, in addition to reducing direct solar radiation on the lettuce plants. These conditions, mainly in chromatinet and black nets, may have promoted a longer period of active photosynthesis, less breathing and no induction of early flowering in the studied cultivars, which is why they developed better in these environments.

Even with the temperature above the recommended in shaded environments with black and chromatinet ${ }^{\circ}$ nets, the solar radiation inside these environments presented an optimal average for the best development of the plants. Therefore, the best development range for the studied lettuce cultivars was from 17.6 to $19.5 \mathrm{MJ} \mathrm{m}^{-2}$ day $^{-1}$, values observed in the environments under black and chromatinet ${ }^{\circ}$ nets, providing a higher total crisphead lettuce yield. Tropical regions all over the world have radiation values in open field conditions at some time of the year higher than the optimum found in the present study; Dangola in Sudan, Dagget in the United States of America and Porto Alegre in Brazil had maximum values of 27.70, 31.3 and $22.1 \mathrm{MJ} \mathrm{m}^{-2}$ day $^{-1}$ (Tiba, 2000). Ojeda et al., (2012), evaluating the production of lettuce in different environments in Colombia, observed that in the summer, production of this vegetable in open field is impaired when compared to covered with plastic, with the mean global solar radiation value indicated as $30.0 \mathrm{MJ} \mathrm{m}^{-2}$ day $^{-1}$ under full sun. Therefore, the cultivation of crisphead lettuce would be compromised in these regions since they have global solar radiation values above those found as excellent (from 17.6 to $19.5 \mathrm{MJ} \mathrm{m}^{-2}$ day $^{-1}$ ), and using black and chromatinet ${ }^{\circ}$ shading nets would be an alternative for offering this vegetable on the market throughout the year.

As for the cultivars, there was a different response for each of them in each different environment, with this variation resulting from the adaptive capacity of the genetic material used. Balsamo and Delícia cultivars had the highest commercial yield when grown in beds covered with chromatinet ${ }^{\circ}$. These results follow the trend proposed by Brzezinski et al. (2017) when studying the production of crisphead lettuce cultivars under open sky and shaded environment with polyethylene in the conditions of União de Vitória - PR, where the greatest production occurred in shaded environments.

\section{Conclusions}

Using black, chromatinet and red shading nets influence the agronomic characteristics of crisphead lettuce grown in the period of high temperatures. The range from 17.6 to 19.5 MJ $\mathrm{m}^{-2}$ day $^{-1}$ of global solar radiation was ideal for producing the crisphead lettuce.

Cultivars produced under effect of the chromatinet ${ }^{\circ}$ net showed higher production and yield. While under black net, all cultivars attained good yield in terms of production. 
Cv. Balsamo achieved the highest total production, cv. Delícia emerged as the highest "head" yield, showing greater commercial yield with the cv. Balsamo, both under the chromatinet ${ }^{\circ}$.

\section{Literature Cited}

Aquino, C. F.; Silva, H. P.; Neves, J. M. G.; Aquino, F. F.; Costa, C. P. M.; Costa, C. A. Performance of lettuce cultivars under hydroponic cultivation in the north of Minas Gerais. Revista Brasileira de Agricultura Irrigada, v. 11, n. 3, p. 1382-1388, 2017. https://doi. $\operatorname{org} 10.7127 /$ rbai.v11n300604,

Blind, A. D.; Araujo, F. S.; Figueiro, J. N. R.; Silva Filho, D. F. Elongação precoce do caule em plântulas de alface americana. Global Science and Technology, v. 10, n. 2, p. 49-57, 2018. https://rv.ifgoiano.edu. br/periodicos/index.php/gst/article/view/893/553. 10 Ago. 2019.

Blind, A. D.; Silva Filho, D. F. Desempenho produtivo de cultivares de alface americana na estação seca da Amazônia Central. Bioscience Journal, v. 31, n. 2, p. 404-414, 2015. https://dx.doi. org/10.14393/BJ-v31n2a2015-22352. 02 Ago. 2019.

Brzezinski, C. R.; Geller, A.; Abati, J.; Werner, F.; Zucareli, C. Produção de cultivares de alface americana sob dois sistemas de cultivo. Ceres, v. 64, n. 1, p. 83-89, 2017. https://doi.org/10.1590/0034737X201764010012.

Companhia de Entrepostos e Armazéns Gerais de São Paulo CEAGESP. Produtos CEAGESP. http://www.ceagesp.gov.br/ produtos/alface-americana . 05 Fev. 2018.

Comissão Estadual de Fertilidade do Solo da Bahia - CEFSBA. Manual de adubação e calagem para Estado da Bahia. Salvador: CEPLAC/ EMATER-BA/EPABA/NITROFÉRTIL, 1989. 176p.

Diamante, M.S.; Seabra Junior, S.; Inagaki, A.M.; Silva, M.B.; Dallacort, R. Produção e resistência ao pendoamento de alfaces tipo lisa cultivadas sob diferentes ambientes. Revista Ciência Agronômica, v. 44, n. 1, p. 133-140, 2013. http://ccarevista.ufc.br/seer/index. php/ccarevista/article/view/1942. 28 Jul. 2019.

Empresa Brasileira de Pesquisa Agropecuária - Embrapa. Sistema brasileiro de classificação de solos. Brasília: Embrapa-PI, 2013. $353 \mathrm{p}$.

Ferreira, D.F. SISVAR Versão 5.3. Lavras: Departamento de Ciências Exatas; UFLA, 2010.

Gonçalves, F.M.; Sento-Sé, G.V.T.; Gomes, A.S.; Yuri, J.E.; Resende, G.M.; Costa, N.D.; Ferreira, T.D.; Mota, J.H. Competição de cultivares de alface americana nas condições de inverno no Submédio do Vale do São Francisco. Horticultura Brasileira, v.31, n.2, p.1023-1030, 2014. https://www.alice.cnptia.embrapa.br/ bitstream/doc/997764/1/Jony5.pdf. 02 Ago. 2019.

Hassanien, R.H.E.; Ming, L. Influences of greenhouse-integrated semitransparent photovoltaics on microclimate and lettuce growth. International Journal of Agricultural and Biological Engineering, v. 10, n. 6, p. 11-22, 2017. https://doi.org/10.25165/j. ijabe.20171006.3407.

Hortfruit. Centro de Estudos Avançados em Economia Aplicada - CEPEA. Panorama e perspectivas de mercado de folhosas. http://www.abcsem.com.br/upload/arquivos/Panorama_e_ perspectivas_de_mercado_de_folhosas_-_Larissa_Pagliuca.pdf . 02 Abr de 2018.
Ilić, S. Z.; Milenković, L.; Dimitrijević, A.; Stanojević, L.; Cvetković, D.; Kevrešan, Ž.; Mastilović, J. Light modification by color nets improve quality of lettuce from summer production. Scientia Horticulturae, v. 226, p. 389-397, 2017. https://doi.org/10.1016/j.scienta.2017.09.009.

Kosma, C.; Triantafyllidis, V.; Papasavvas, A.; Salahas, G.; Patakas, A. Yield and nutritional quality of greenhouse lettuce as affected by shading and cultivation season. Emirates Journal of Food and Agriculture, v. 25, n.12, p. 974-979, 2013. https://doi.org/ 10.9755/ejfa.v25i12.16738.

Lemos Neto, H. S.; Guimarães, M. A.; Tello, J. P. J.; Mesquita, R. O.; Dovalle, J. C.; Lima Neto, B. P. Productive and physiological performance of lettuce cultivars at diferente planting densities in the Brazilian Semiarid region. African Journal of Agricultural Research, v. 12, n. 10, p.771-779, 2017. https://doi.org/10.5897/AJAR2016.11961.

Neves, J. F. N. F.; Nodari, I. D. E.; Júnior, S. S.; Dias, L. D. E.; Silva da, L. B.; Dallacort, R. Produção de cultivares de alface americana sob diferentes ambientes em condições tropicais. Revista Agro@ mbiente On-line, v. 10, n. 2, p. 130-136, 2016. http://dx.doi. org/10.18227/1982-8470ragro.v10i2.3200.

Ntsoane, L.M.; Soundy, P.; Jifon, J.; Sivakumar, D. Variety-specific responses of lettuce grown under the different-coloured shade nets on phytochemical quality after postharvest storage. Journal of Horticulture Science and Biotechnology, v.91, n.5, p.520-528, 2016. https://doi.org/10.1080/14620316.2016.1178080.

Ojeda, A.D.; Ligarreto, G.A.; Martinez, O. Efeitos de fatores ambientais nas características morfométricas de alface cultivada (Lactuca sativa L.). Agronomia Colombiana, v. 30, n. 3, p. 351-358, 2012. http://www.scielo.org.co/scielo.php?script=sci_arttext\&pid=S01 $2099652012000300006 \&$ Ing=en\&nrm=iso. 28 Jul. 2019.

Rampazzo, R.; Junior, S. S.; Nunes, M. C. M.; Silva Neves da, S. M. A.; Ferreira, R. F. Eficiência de telas termorefletoras e de sombreamento em ambiente protegido tipo telado sob temperaturas elevadas. Revista Engenharia na Agricultura, v. 22, n. 1, p. 33-42, 2014. https://doi.org/10.13083/reveng.v22i1.362.

Rebouças, P. M.; Dias, Í. F.; Alves, M. A.; Barbosa Filho, J. A. D. Radiação solar e temperatura do ar em ambiente protegido. Revista Agrogeoambiental, v. 7, n. 2, p. 115-125, 2015. https:// doi.org/10.18406/2316-1817v7n22015610.

Sales, F.A.; Barbosa Filho, J.A.D.; Barbosa, J.P.R.A.D.; Viana, T.V.A.; Freitas, C.A.S. Telas agrícolas como subcobertura no cultivo de alface hidropônica. Ciência Rural, v.44, n.10, p.1755-1760, 2014. https://doi.org/10.1590/0103-8478cr20120633.

Santi, A.; Carvalho, M. A. C.; Campos, O. R.; Silva, A. F.; Almeida, J. L.; Monteiro, S. Ação de material orgânico sobre a produção e características comerciais de cultivares de alface. Horticultura Brasileira, v. 28, n. 1, p. 87-90, 2010. https://doi.org/10.1590/ S0102-05362010000100016.

Santi, A; Scaramuzza, W.L.M.P.; Neuhaus, A.; Dallacort, R.; Krause, W.; Tleppo, R.C. Desempenho agronômico de alface americana fertilizada com torta de filtro em ambiente protegido. Horticultura Brasileira, v.31, n.2, p. 338-343, 2013. https://doi.org/10.1590/ S0102-05362013000200027.

Santiago, E. J. P.; Oliveira, G. M.; Ramos, M. D. M. V. B.; Rocha, R.C; Silva, R. R. Condições microclimáticas proporcionadas por tela de sombreamento no cultivo do tomate cereja. Agrometeoros, v. 25, n. 1, 2018. http://seer.sct.embrapa.br/index.php/agrometeoros/ article/view/26275/13883 . 17 Mar. 2019. 
Sousa, T. P. de; Souza Neto, E. P.; Silveira, L. R. de S.; Santos Filho, E. F.; Maracajá, P. B. Produção de alface (Lactuca sativa L.), em função de diferentes concentrações e tipos de biofertilizantes. Revista Verde, v. 9, n. 4, p.168-172, 2014. http://www.gvaa.com. br/revista/index.php/RVADS/article/view/2886. 13 Mar. 2019.

Teixeira, H.A.C. Informações agrometeorológicas do polo Petrolina, PE/Juazeiro, BA - 1963 a 2009. Petrolina: Embrapa Semiárido, 2010. 21p. (Embrapa Semiárido. Documento, 233).

Tiba, C. (Coord.). Atlas solarimétrico do Brasil: banco de dados solarimétricos Recife: Ed. Universitária da UFPE, 2000. 111p. http://www.cresesb.cepel. br/index.php?section=publicacoes\&task=livro\&cid=2.10 Ago. 2019.
Yuri, J.E.; Resende, G.M.; Costa, N.D.; Gomes, A.S. Desempenho agronômico de genótipos de alface americana no Submédio do Vale do São Francisco. Horticultura Brasileira, v.35, n.3, p. 292-297, 2017. https://doi.org/10.1590/S0102053620170222.

Yuri, J.E.; Resende, G.M.; Mota, J.H.; Souza, R.J.; Rodrigues Júnior, J.C. Comportamento de cultivares e linhagens de alface Americana em Santana da Vargem (MG), nas condições de inverno. Horticultura Brasileira, v.22, n.2, p.322-325, 2004. https://doi. org/10.1590/S0102-05362004000200032. 